\title{
ORMOC BAY NAVAL BATTLE OF DECEMBER 3, 1944 - THE LAST VICTORY OF THE IJN SURFACE SHIPS
}

\begin{abstract}
The article examines the last victory of surface ships of the Japanese Imperial Fleet over surface ships of the United States Navy, which took place in Ormoc Bay on December 3, 1944. Because of mistakes during the preparation and conduct of the battle, superior US force was unable to destroy Japanese convoy and was forced to retreat.

The purpose of the article is to investigate the actions of surface ships of the United States Navy against the enemy surface ships in Ormoc Bay on December 3, 1944, and to analyze the causes of their failure.

The Ormoc Bay battle provides us with a good example of independent actions of small US surface force, unsupported by aviation. The battle clearly demonstrated, that superior combat power of the ships and well-trained crews does not guarantee victory in the absence of the factors which author describes in the article.

While this small battle hardly changed outcome of the battle for Leyte or introduced something new in naval warfare, it shows us, that without air support US surface ships' actions were far from perfect. This battle also confirms enormous importance of planning and leadership in naval battles, where success often lies in meticulous planning and swift, but sound command decisions.
\end{abstract}

Key words: Pacific Ocean theater during World War II, Battle of Leyte, Ormoc Bay Battle, combat operations of surface ship, US navy during WWII.

US victory in the Pacific Ocean area during World War II was impossible without the United States Navy (USN). Backed with enormous industrial might of the United States of America, it rallied after early war defeats at the hands of the Imperial Japanese Navy (IJN) to become strongest fleet in the world. From early 1944 nothing was able to stop its' advance. However, closer look on the USN achievements will show us, that almost all US victories in late war naval battles were brought by naval aviation [1, chapters 12-14, and 6]. Surface ships usually acted as escort for aircraft carriers and finished off damaged Japanese ships. So what was the effectiveness of USN surface ships in the surface combat they were made for? How effective was USN planning and execution of surface combat operations?

Unfortunately, there are very few examples of late war (1944-45) naval battles, where aviation played little or no role. One of those rare examples is Ormoc Bay battle on December 3, 1944, which provides us with a good example of independent actions of small US surface force, unsupported by aviation.

Unfortunately, being relatively small combat episode, Ormoc Bay battle brought little attention from historians. One chapter each from "Leyte, June 1944 - January 1945" [6] and "Matsu gata kuchikukan" [5] are the most detailed accounts of the battle. Unfortunately, those works are focused on describing the battle from their own side, largely ignoring information from the opposite side. Another important and relatively recent contribution to the researcher of the battle, missing from previous works, is the 
information from the official web page of DD-692 Allen M. Sumner at http://www.dd692.com. Ormoc Bay battle was the first combat action of this ship, so web page devotes significant attention to it, presenting, among other information, scans of original documents (reports, logs) from the US side, made either during the battle or immediately after it [3, 11-17]. Those documents present information about US ships' actions and its' assessment by US commanders without later "post factum" knowledge, that often clouds historians' judgment.

Strategic and tactical background. By December 1944 course of the Second World War in the Pacific clearly turned to the favor of the United States of America and their allies. For more than a year, land and naval forces of the Japanese Empire suffered defeat after defeat, while US forces were getting closer and closer to Philippine Islands, which guarded the main supply route of the Japanese Empire.

On October 20, 1944, troops of US Sixth Army landed on Leyte Island in the central part of the Philippines. IJN send almost all available ships to destroy invasion force, but failed to get past the forces of the United States Navy. In the great naval battle at Leyte Gulf (23-26 October 1944) IJN was defeated, so USN could now freely supply and reinforce US Army troops on Leyte. Even masses Japanese air attacks, including those made by suicide pilots of the "kamikaze" forces, failed to stop the flow of US supplies and reinforcements to Leyte [2, P. 478-487].

All Japanese could now do was to draw US Army troops into pitched battles against defenses of the Imperial Japanese Army (IJA) on Leyte in hope, that overwhelming US losses will stop further American advance. However, in order to do it Japanese troops on Leyte had to be well supplied and reinforced [2, P. 489]. This task fell to IJN, which organized "TA" convoy operation from Manila (Luzon Island) to Ormoc Bay on Leyte Island $[8,9,10]$.

Naturally, US forces tried to intercept those convoys, using aviation, and finally torpedo boats and destroyers. On the night of November 27/28, 1944, after two minesweepers swept southern approach to Ormoc Bay, four Fletcher-class destroyers, with a PBY "Catalina" flying boat doing the reconnaissance, steamed into the bay. They found no transports, but shelled Ormoc dock area and even claimed (erroneously ${ }^{1}$ ) one enemy submarine sunk [6, P.369]. The next night four PT boats went into Ormoc Bay to report a freighter and a patrol craft sunk. Though their real victims were patrol boat $P$ 105 and submarine chaser $C h-53$, this was definitely a success [6, P.369-370; 4, P.19]. Two more destroyer raids into the Ormoc Bay (on November 29/30 and December 1/2) however, failed to meet any enemy [6, P.370].

But on the morning of December 2 air reconnaissance reports indicated convoy on the way [6, P. 371], so it was decided to send another group of destroyers into the Ormoc Bay.

Movements to contact and the course of the battle. On the evening of December 1, 1944 Japanese destroyers Kuwa (commanding officer - Commander Yamashita Masamichi) and Take (commanding officer - Commander Unagi Tsuyoshi, executive officer and commander of ship's torpedo division - Lieutenant Shiga Hiroshi) escorted high-speed transports T-9, T-140 and T-159 from Manila to Ormoc Bay to bring

\footnotetext{
${ }^{1}$ The only IJN submarine sunk on November 27, 1944 (I-46) was sunk to the east of Leyte Island [4, P. 19].
} 
reinforcements and supplies for the Japanese troops on Leyte as part of the convoy operation TA-7 [5, P. 98, 10]. Due to bad weather ships reached their destination at the evening of December 2, 1944 unmolested by the US aviation. On entering the bay transports approached its north-eastern shore and began unloading supplies and disembarking troops while destroyers took the patrol positions inside the bay at a distance of $300 \mathrm{~m}$ from each other and started patrolling at a speed of 6 knots. Take patrolled to the north, and Kuwa - to the south of the unloading point [5, P. 98].

On the other side at $18.29^{2}$ on December 2, 1944 three US destroyers left Leyte Gulf and headed south through Surigao Strait towards Ormoc Bay to destroy enemy ships according to the orders of the Commander of the Task Force 77 [3]. Those destroyers were DD-692 Allen M. Sumner (commanding officer - Commander Norman J. Sampson), DD-693 Moale (commanding officer - Commander Walter M. Foster) and DD-695 Cooper (commanding officer - Commander Mell A. Peterson). All ships belonged to the Destroyer Division 120, led by Commander John C. Zahm, who was aboard Sumner [3].

At 23.08 Allen M. Sumner was attacked by Japanese plane [3]. Ship evaded dropped bomb, but still received some damage from close bomb explosion and several of her sailors were wounded [16]. This sudden attack apparently had unforeseen consequence: during the whole battle Allen M. Sumner constantly fought with Japanese aircraft, some of them were "seen" only by Sumner's crew (other destroyers failed to see them) $)^{3}$.

Shortly after midnight on December 3, 1944, US destroyers entered Ormoc Bay. They were in line formation (left to right: Allen M. Sumner, Cooper and Moale) to make full use of their strong 4-gun forward battery [3]. Couple of minutes later (00.05) Sumner shelled small port village of Albuera, claiming one ammunition barge sunk [16]. Discovering the enemy, Kuwa rushed to intercept while Take went to take good position to attack enemy ships with torpedoes [5, P. 98].

It would seem that three US destroyers of the latest type with six 5-inch guns aboard each ship [18] would make short work of two small Japanese destroyers which had only three 5-inch guns each [5, P. 83]. However, that was not the case.

Discovering both Japanese destroyers, US ships opened fire at 00.09 and quickly made hits. But the fire of US destroyers was concentrated only on the nearest Japanese destroyer $-\mathrm{Kuwa}^{4}$, which allowed Take to take a good position for the torpedo attack. Lieutenant Shiga gave the order to fire, but torpedoes were not launched, perhaps due to the damage of the cable connecting the torpedo control panel on bridge with the torpedo mount [5, P. 98]. At this time Take finally begun receiving fire from Moale, but her director could not immediately pick the new Japanese target up, so fire was resumed on Kuwa [13]. This unwise decision probably saved Take, because when at 00.12 she went under fire from the Cooper, she was almost ready for another torpedo attack. Firing torpedoes under enemy fire and by the local sights of the torpedo mount is not the easiest thing to do (especially at night), but Lieutenant Shiga managed to get excellent result: at

\footnotetext{
${ }^{2}$ All times are local.

${ }^{3}$ See "talk between ships" tactical radio logs of Sumner and Moale [14 and 17].

${ }^{4}$ It seems, that Japanese destrouers were first shelled by Moale, while Cooper joined couple minutes later and Sumner - even later on. Ships' Official Action Report present confusing picture. [See 11, 13, 16].
} 
00.15 one 61-cm oxygen torpedo (from a two-torpedo salvo) fired from a distance of about $6000 \mathrm{~m}$, hit the starboard ${ }^{5}$ side of the Cooper [5, P. 99]. Powerful torpedo explosion in the middle of the ship broke US destroyer in half, and in 30 seconds both parts of the ship went to the bottom together with 191 sailors from her crew [11].

All this time, Kuwa continued to stubbornly return fire, despite many hits and severe fire on board, until she had finally sunk at 00.19 [16].

It would seem that now two US destroyers will quickly get a lonely Take, especially after she failed to hit US ships with her third (and the last) torpedo [7, P. 143]. But all this time US ships fought not only Take and Kuwa, but also torpedo boats, aircraft and coastal batteries $[11 ; 13 ; 16]$. In reality this crowd of enemies never existed, except for aircraft ${ }^{6}$, but it diverted attention of US ships' crews just like the real enemies ${ }^{7}$. Confusion aboard Sumner was so great, that even Cooper sinking went unnoticed and Commander Zahm found about it only at 00.29 after the report from the Moale [3].

Thanks to this "ghost hunt", Take received very few hits in this battle: except for minor damage from small-caliber projectiles and splinters, the destroyer received only one direct hit of a 5-inch shell into the forward engine room. The shell had pierced the port side, gone between the engines and stopped on the starboard side without exploding or even wounding anybody inside the engine room. It was a small miracle that for all the fire from US destroyers the only hit had been a dud. During the whole battle only one person aboard Take had been injured. Still, forward engine went out of order and the forward engine room began to flood (eventually the list reached 30 degrees) [5, P.99]. The stubborn resistance of Take, the "ghost hunt" and news of the sinking of Cooper convinced Commander Zahm to order withdrawal at 00.32. Sumner and Moale turned to the south and left the Ormoc Bay at full speed, without stopping to rescue survivors from the Cooper [3]. On the way to the base US destroyers were again attacked by the Japanese aircraft (air attacks on the Sumner continued until 01.45) [6, P. 371], which managed to damage both Sumner [16] and Moale [13]. In addition, after the battle one Japanese shell was found in the stern plate of the Moale [13]. Fortunately, it failed to explode just like the US shell, which hit Take. This "exchange of duds" is a unique phenomenon of this battle.

Post-battle. Survivors from the Cooper floated around the bay until c.14.00, when PBY flying boats finally come to rescue them (rescue operations continued until dark) [6, P. 372]. Shortly after the dawn, one group of Cooper survivors appeared not far from the group of survivors from the Kuwa, someone among whom spoke English. No details of this conversation are available, but it is not hard to imagine words, exchanged by the people who tried to kill each other only a couple hours ago [6, P. 372]. Take crew did not even have the opportunity to save the crew of the Kuwa, because now

${ }^{5}$ Japanese account of the battle [5, P. 99] erroneously claims, that Cooper was hit at the port side, however ship's Official Action Report is clear, that she was hit at the starboard side.

${ }^{6}$ Fire from coastal batteries was most likely fire from Take or moored transports, though latter's position makes this extremely unlikely.

${ }^{7}$ It's interesting to note, that Sumner's and Cooper's reports mention a lot of air attacks but no torpedo boat attacks, while Moale's report mentions air and torpedo boat attacks in equal measure [Compare 11, 13 and 16]. 
damaged Take was the sole escort of the TA-7 convoy [5, P. 99]. So rescue of the Kuwa crew was entrusted to the personnel of the Ormoc base, while Take together with his wards at 03.00 on December 3, 1944, begun her journey back to Manila, where convoy arrived in the afternoon next day without any US attacks [7, P. 149; 10]. On return to Manila Commander Unagi was personally commended by the Commander in Chief of the Southwestern Area Fleet Vice-Admiral Okawachi Denshichi [5, P. 99]. But it is unlikely that he or anybody else suspected, that Take had just participated in the historic event: the last victory of the IJN surface ships in combat against enemy surface ships.

Conclusions. For obvious reasons, victories are more popular subjects of historical description, then losses. But losses usually provide us with better lessons.

During the war American sailors regularly displayed both skill and courage. Even after US Navy greatly increased in size, there was no noticeable drop in quality of ships' crews. However, navy is more, than a collection of ships' crews - it's an organization highly dependent on the efficiency of pre-battle planning and the efficiency of command and control in battle itself. Ormoc Bay battle on December 3, 1944 clearly demonstrated, that superior combat power of the ships and well-trained crews does not guarantee victory in the absence of the above-mentioned factors.

The following mistakes had to be pointed out.

1. The choice of the ships from Destroyer Division 120 for this mission was obviously a poor one, as they had no combat experience $[13 ; 16]$. Inexperienced crews were not quite ready for the close combat, yet alone for the close combat at night.

2. Lack of any air support, save for air reconnaissance, is surprising. USN had PBY "Catalina" flying boats, trained for operations at night (so called "Black Cats"), yet they were only used for air reconnaissance of Ormoc Bay. Air support would have been a great help to US force, as it was during the similar mission on November 27.

3. Advanced radars and fire control systems of new Sumner-class of destroyers (all three US ships belonged to this class) apparently brought the false sense of superiority and reluctance to use illuminating shells, etc. However, US radar was not an all-seeing device and had trouble identifying targets against the coastline. There were other troubles with gunnery control [13].

4. From the beginning of the battle with Japanese destroyers, Commander Zahm lost control of the situation so completely, that even in the official report about this battle he could not accurately describe actions of his ships. As a result, each ship acted without coordination with other ships, thus negating overall US superiority.

5. Commander Zahm decided that the scattered small targets could be more effectively dealt with by gunfire, saving the torpedoes for more suitable targets if they should appear [3]. Unwillingness to use torpedoes together with poor US gunnery led to inability to quickly finish off Kuwa and concentrate on Take. Of course, difference between "quickly" and "not quickly" in this battle measured in only several minutes - but it was long enough to lose Cooper.

6. The "ghost hunt" against non-existent targets not just led to the dispersal of efforts - it brought false feeling of being outnumbered that led to withdrawal of US ships.

As a result of the abovementioned factors, instead of sure destruction of Japanese convoy US ships were forced to retreat by an inferior force, losing one destroyer and allowing Japanese to resupply the defense of Leyte. It is worth noting, that of four US battle reports (Commander's DesDiv 120 and three ships' Commanding Officers) only Commander Foster of Moale made critical remarks about his own performance in this 
battle [13]. Other commanders were, apparently, sure, that they did everything right and there was no need for improvement of or reflections on their actions $[3 ; 11 ; 16]$. Therefore, it is not surprising, that according to the official results of the battle Commander Zahm recommended all three destroyers' commanding officers to the Silver Star Medal [3].

On the contrary, commanders of Japanese destroyers, despite being taken by surprise, acted quickly and according to the situation, successfully using the only weapon that could give them advantage over superior enemy - torpedoes. Even suicidal charge of Kuwa was the only way to deal with this situation, as it drew attention of US destroyers from Take and transports [5, P. 98]. Take's commanding officer used Kuwa's sacrifice well, wisely refusing to engage in close combat with superior enemy while trying to solve battle with torpedoes.

While this small battle hardly changed outcome of the battle for Leyte or introduced something new in naval warfare, it shows us, that without air support US surface ships' actions were far from perfect. This battle also confirms enormous importance of planning and leadership in naval battles, where success often lies in meticulous planning and swift, but sound command decisions. This last lesson is still important even now and definitely warrants further studies - after all, despite all the advances in technology, decisionmaking process is still in the hands of humans.

\section{Sources}

1. Нимиц Ч.У, Поттер Э.Б. Война на море (1939-1945) /Ч.Нимиц, Э.Поттер. - Смоленск: Русич, 1999. - 592 с.

2. Хаттори Т. Япония в войне 1941-1945 гг. - Москва: Военное издательство Министерства обороны СССР, 1973. - 880 с.

3. Commander Destroyer Division ONE-TWENTY Action Report [Electronic resource]. - Mode of Access: http://www.dd-692.com/cdd_120_action_report.htm (last access: July 5, 2017). - Title from the Screen.

4. Japanese Naval and Merchant Shipping Losses During World War II by All Causes. Washington DC: U.S. Government Printing Office, NAVEXOS P-468, 1947.

5. Matsu gata kuchikukan [Matsu-class destroyers]// Gakken Rekishi gunzo No. 43. - Tokyo, 2003.

6. Morison S. Leyte, June 1944 - January 1945. // History of United States Naval Operations in World War II. Volume 12. - Castle Books; Reprint edition, 2001 [1956]. - 512 p.

7. Moro H. Nankai no shito - shonen suihei no umi senki [South Seas mortal combat - young sailor's sea battles]. - Tokyo, 1994.

8. Nevitt A. TA Operations to Leyte, Part I [Electronic resource]. - Mode of Access: http://www.combinedfleet.com/taops1.htm (Last Access: July 5, 2017). - Title from the Screen.

9. Nevitt A. TA Operations to Leyte, Part II [Electronic resource]. - Mode of Access: http://www.combinedfleet.com/taops2.htm (Last Access: July 5, 2017). - Title from the Screen.

10. Nevitt A. TA Operations to Leyte, Part III [Electronic resource]. - Mode of Access: http://www.combinedfleet.com/taops3.htm (Last Access: July 5, 2017). - Title from the Screen.

11. USS Cooper's Official Action Report. Serial: 00503 [Electronic resource]. - Mode of Access: http://www.dd-692.com/cooper's.htm (Last Access: July 5, 2017). - Title from the Screen.

12. USS Moale's Deck Log [Electronic resource]. - Mode of Access: http://www.dd692.com/images/nonsumner/moale01.jpg (Last Access: July 5, 2017). - Title from the Screen.

13. USS Moale's Official Action Report. Serial 086 [Electronic resource]. - Mode of Access: http://www.dd-692.com/moale's.htm (Last Access: July 5, 2017). - Title from the Screen.

14. USS Moale's Official TBS (talk between ships) Tactical Radio Log [Electronic resource]. Mode of Access: http://www.dd-692.com/images/other/ormocbay/obtbs07.jpg (Last Access: July 5, 2017). - Title from the Screen. 
15. USS Sumner's Deck Log [Electronic resource]. - Mode of Access: http://www.dd692.com/images/logbooks/1944/lg441202a.jpg (Last Access: July 5, 2017). - Title from the Screen.

16. USS Sumner's Official Action Report. Serial 089 [Electronic resource]. - Mode of Access: http://www.dd-692.com/action.htm (Last Access: July 5, 2017). - Title from the Screen.

17. USS Sumner's Official TBS (talk between ships) Tactical Radio Log [Electronic resource]. Mode of Access: http://www.dd-692.com/images/other/ormocbay/obtbs01.jpg (Last Access: July 5, 2017). - Title from the Screen.

18. USS Sumner's Ship Specifications [Electronic resource]. - Mode of Access: http://www.dd692.com/specific.htm (Last Access: July 5, 2017). - Title from the Screen.

\section{Sources}

1. NIMITZ, C., POTTER, E. (1999) Voyna na more (1939-1945). - Smolensk: Rusich.

2. HATTORI, T. (1973) Yaponiya v voyne 1941-1945. - Moscow: Voyennoye izdatel'stvo Ministerstva Oborony SSSR.

3. Commander Destroyer Division ONE-TWENTY Action Report (1944) [Online] - Available from: http://www.dd-692.com/cdd_120_action_report.htm (accessed July 5, 2017).

4. Japanese Naval and Merchant Shipping Losses During World War II by All Causes (1947). Washington DC: U.S. Government Printing Office, NAVEXOS P-468.

5. Matsu gata kuchikukan [Matsu-class destroyers] (2003) // Gakken Rekishi gunzo No. 43.

6. MORISON, S. (2001) Leyte, June 1944 - January 1945. // History of United States Naval Operations in World War II. Volume 12. - Castle Books.

7. MORO, H. (1994) Nankai no shito - shonen suihei no umi senki [South Seas mortal combatyoung sailor's sea battles]. Tokyo.

8. NEVITT, A. (1996) TA Operations to Leyte, Part I [Online] - Available from: http://www.combinedfleet.com/taops1.htm (accessed July 5, 2017).

9. NEVITT, A. (1996) TA Operations to Leyte, Part II [Online] - Available from: http://www.combinedfleet.com/taops2.htm (accessed 5 July 2017).

10. NEVITT, A. (1996) TA Operations to Leyte, Part III [Online] - Available from: http://www.combinedfleet.com/taops3.htm (accessed 5 July, 2017).

11. USS Cooper's Official Action Report. Serial: 00503 (1944) [Online] - Available from: http://www.dd-692.com/cooper's.htm (accessed July 5, 2017).

12. USS Moale's Deck Log (1944) [Online] - Available from: http://www.dd692.com/images/nonsumner/moale01.jpg (accessed July 5, 2017).

13. USS Moale's Official Action Report. Serial 086. (1944) [Online] - Available from: http://www.dd-692.com/moale's.htm (accessed July 5, 2017).

14. USS Moale's Official TBS (talk between ships) Tactical Radio Log (1944) [Online] Available from: http://www.dd-692.com/images/other/ormocbay/obtbs07.jpg (accessed July 5, 2017).

15. USS Sumner's Deck Log (1944) [Online] - Available from: http://www.dd692.com/images/logbooks/1944/lg441202a.jpg (accessed July 5, 2017).

16. USS Sumner's Official Action Report. Serial 089 (1944) [Online] - Available from: http://www.dd-692.com/action.htm (accessed July 5, 2017).

17. USS Sumner's Official TBS (talk between ships) Tactical Radio Log (1944) [Online] Available from: http://www.dd-692.com/images/other/ormocbay/obtbs01.jpg (accessed July 5, 2017).

18. USS Sumner's Ship Specifications (1944) [Online] - Available from: http://www.dd692.com/specific.htm (accessed July 5, 2017).

Надійшла до редколегії 19.04.2017 
Свген Пінак, магістр правознавства, член правління громадської організачії «Українська Асочіачія Американістики»

\title{
БІЙ В БУХТІ ОРМОК 3 ГРУДНЯ 1944 Р. - ОСТАННЯ ПЕРЕМОГА ЯПОНСЬКИХ НАДВОДНИХ КОРАБЛІВ
}

Анотація. В статті розглянута остання перемога надводних кораблів Японського імперського флоту над надводними кораблями Військово-морських сил США, що відбулась в бухті Ормок 3 грудня 1944 р. Через помилки під час підготовки та проведення бою переважаючі сили американців не змогли знищити японський конвой та були змушені відступити.

Метою статті є дослідження дій надводних кораблів Військово-морських сил США проти надводних кораблів противника в бухті Ормок 3 грудня 1944 р. та аналіз причин їх невдачі.

Битво в бухті Ормок є показовим прикладом незалежних дій незначних наземних сил армї США за відсутності підтримки з боку авіації. Вона стала демонстрацією того, щзо переважаючий потениіал бойових суден та добре підготовлений екіпаж на стали запорукою перемоги у зв'язку з циілою низкою факторів, які автор описує в статті.

Не зважаючи на те, щчо ия порівняно невелика битва майже не змінила результати битви біля Лейте і не внесла чогось нового в теорію військово-морських операцій їі хід став підтвердженням неможливості надводних військово-морських суден США здійснювати ефективні операчії без повітряної підтримки. Цей бій, також, підтвердив надзвичайну важливість планування, лідерських якостях та точних ріменнях командування військово-морських операчій.

Ключові слова: Тихоокеанський театр воєнних дій Другої світової війни; битва біля Лейте; Битва в бухті Ормок; Бойові операції надводних сил; ВМС США під час Другої світової війни.

\section{УДК 94(73)}

\author{
Nikolai Saychuk, \\ Ph.D. in History, \\ Board member of the Ukrainian Association \\ for American Studies
}

\section{THE OPERATIONAL PLANNING AND PREPARATION OF SOVIET LANDING IN THE BLACK SEA STRAITS}

\begin{abstract}
The article deals with the operational planning and preparation of Soviet landing in the Black Sea Straits during the Cold War. Emphasized that because of the inability of Turkish garrisons to keep the defence on their own, the arrival of strong US reserves was expected to retain Central Turkey and Asian shore of the Dardanelles Strait. Command of the Soviet Army and the Combined Armed Forces of the member states of the Warsaw Pact could not rely on the quick success of the operation regarding the Black Sea Straits capture and placed stake on the widespread use of nuclear weapons.

The aim of research is the study of the operations preparation in Europe during the Cold War and the possible participation of American forces. To capture Bosporus Straits area, the planning, which was based on a strategic map game and on front command-staff exercises of the Commander of the Odessa Military District on 1969, called for up to five air army sorties and an allotment of 12 to 15 nuclear bombs, constituting 18-20\% of the nuclear munitions expended by
\end{abstract}

